\title{
High latitude, deeper water coral bleaching at Rottnest Island, Western Australia
}
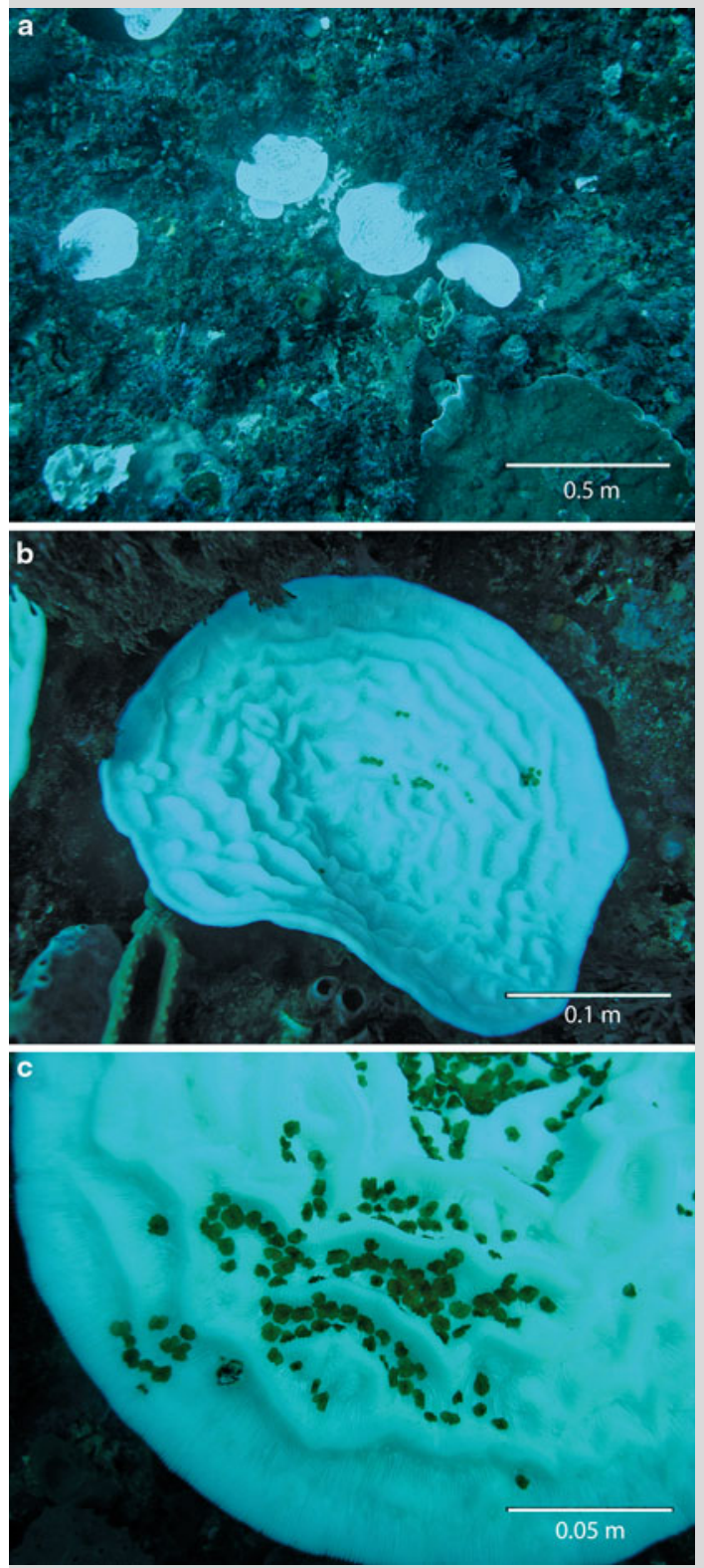

Fig. 1 Coral bleaching in a water depth of $28 \mathrm{~m}$ at Rottnest Island (May 2011), a bleached colonies of Coscinaraea marshae adjacent to an unbleached colony of Montipora sp., b close-up of a bleached colony of C. marshae., $\mathbf{c}$ flatworms on a bleached colony of C. marshae
Coral bleaching is well documented on shallow, tropical reefs; however, there are few published records of coral bleaching on high latitude $\left(>26^{\circ}\right)$, deeper $(>20 \mathrm{~m}$ ) reefs (see Harrison et al. 2011 for a recent example of bleaching on a high latitude, shallow reef). High latitude, deeper reefs are thought to be less affected by thermal stress and therefore may act as potential refuge sites from the adverse impacts of global warming (Bongaerts et al. 2010). Here, we observed extensive species-specific coral bleaching in May 2011 at two high latitude, deeper (24-28 m) reefs located on the western side of Rottnest Island, Western Australia $\left(32^{\circ} 00^{\prime} \mathrm{S}, 115^{\circ} 31^{\prime} \mathrm{E}\right)$. Rottnest Island has well-developed coral assemblages that include 25 species in 16 genera (Veron and Marsh 1988). Most colonies of Coscinaraea marshae $(n \approx 100)$, a species endemic to southern Australia, were completely bleached and colonized by flatworms, while all other coral genera were unbleached (Fig. 1). Ninety-five percent of bleached colonies of $C$. marshae remained alive after 4 weeks, although partial mortality was evident in approximately $20 \%$ of colonies. Water temperatures between December 2010 and May 2011 at these sites were higher than average and NOAA SST records reveal 16-degree heating weeks (DHW) for the region (http://www.osdpd.noaa.gov/data/cb/dhw/2011/dhwg.5.30.2011.gif). In situ measurements recorded hourly by Hobo $^{\mathrm{TM}}$ loggers confirmed temperatures were up to $4^{\circ} \mathrm{C}$ higher $\left(\right.$ maximum $=26.4^{\circ} \mathrm{C}$ ) than the long-term monthly average $\left(21.5-21.9^{\circ} \mathrm{C}\right)$ for the 150 days prior to surveys (December 27, 2010 to May 25, 2011), and these above average temperatures extended to a depth of greater than $50 \mathrm{~m}$. Our observations confirm that corals located on deeper, high latitude reefs are susceptible to thermal bleaching. Interestingly, at this location, $C$. marshae is close to the northern limit of its range (Veron and Marsh 1988), which may explain why it is more susceptible to thermal stress than the other species at Rottnest Island, most of which have distributions extending further north (Veron and Marsh 1988).

Acknowledgments We thank CSIRO and the IMOS National reference station program for supporting this research.

\section{References}

Bongaerts P, Ridgeway T, Sampayo EM, Hoegh-Guldberg O (2010) Assessing the 'deep reef refugia' hypothesis: focus on Caribbean reefs. Coral Reefs 29:309-327

Harrison PL, Dalton SJ, Carroll AG (2011) Extensive coral bleaching on the world's southernmost coral reef at Lord Howe Island, Australia. Coral Reefs. doi:10.1007/s00338-011-0778-7

Veron JEN, Marsh LM (1988) Hermatypic corals of Western Australia: records and annotated species list. Rec West Aust Mus, Perth (suppl 29):136

D. P. Thomson $(\bowtie) \cdot$ D. Bearham · F. Graham

CSIRO Marine and Atmospheric Research, Wembley, WA 6014, Australia

e-mail: Damian.Thomson@csiro.au

J. V. Eagle

RPS Environment, PO Box 465, Subiaco, WA 6904, Australia

Received: 14 June 2011 / Accepted: 28 July 2011/Published online: 21 August 2011

Coral Reefs (2011) 30:1107

(C) Springer-Verlag 2011 DOI $10.1007 / \mathrm{s} 00338-011-0811-\mathrm{x}$ 